\title{
Czas przeżycia wolnego od progresji choroby nie jest wiarygodnym kryterium oceny wartości przeciwnowotworowego leczenia systemowego
}

\author{
Piotr Rutkowski
}

W pracy przedstawiono, jakie zagrożenia związane są z wyborem czasu przeżycia wolnego od progresji choroby jako kryterium oceny wartości przeciwnowotworowego leczenia systemowego i dlaczego wciąż przeżycie całkowite jest istotnym punktem końcowym dla badań klinicznych w onkologii.

\section{Progression-free survival as a reliable criterion for assessment of the value of systemic anticancer therapy}

Hazards related with the choice of progression-free survival as a criterion for assessment of the value of systemic anticancer therapy are presented in this study. The arguments for overall survival as reliable end-point in clinical trials in oncology are discussed.

NOWOTWORY Journal of Oncology 2016; 66, 1: 68-69

Słowa kluczowe: przeżycie wolne od progresji choroby, przeżycie całkowite, zastępczy punkt końcowy, badanie kliniczne

Key words: progression-free survival, overall survival, surrogate end-point, clinical trial

Przeżycie całkowite (OS - overall survival) przez wiele lat było uważane za „złoty standard" dla oceny skuteczności przeciwnowotworowych terapii systemowych, ale w ostatnich latach przeżycie wolne od progresji (PFS — progression-free survival) jest coraz częściej stosowane jako punkt końcowy badań klinicznych służących rejestracji nowych leków stosowanych w zaawansowanych nowotworach złośliwych [1]. W niniejszej pracy podjąłem próbę przedstawienia zagrożeń związanych z wyborem PFS jako kryterium oceny wartości przeciwnowotworowego leczenia systemowego oraz odpowiedzi na pytanie, dlaczego wciąż OS jest istotnym punktem końcowym dla badań klinicznych w onkologii.

Dla oceny wartości punktu końcowego badania klinicznego konieczne są następujące elementy:

1) jak wiarygodna jest ocena punktu końcowego?

2) jaki jest wpływ leczenia po progresji na punkt końcowy?

3) czy punkt końcowy odzwierciedla korzyść kliniczną?

Uwzględniając te pytania, zgon chorego to jednoznaczny punkt końcowy przeżycia całkowitego i w związku z tym nadal OS jest uznawane za najbardziej wiarygodny punkt oceny skuteczności terapii. PFS pozostaje jedynie zastępczym punktem końcowym dla OS, gdyż ocena PFS jest szybsza do uzyskania w badaniach klinicznych (więc stosowanie PFS jest związane często z presją ekonomiczną) oraz dla wykazania poprawy (uzyskanie istotnych statystycznie różnic) PFS konieczna jest znacznie mniejsza liczba chorych niż dla wykazania poprawy OS [1]. Argumentuje się, że poprawa PFS powoduje korzyści kliniczne w postaci zmniejszenia lęku u chorych, zmniejszenia objawów związanych z chorobą, poprawy jakości życia i wydłużenia czasu bez leczenia. Jednak 3 pierwsze punkty nigdy nie zostały potwierdzone $w$ badaniach klinicznych, a ostatni punkt wykazano jedynie $w$ badaniu prowadzącym do zarejestrowania gemcytabiny z karboplatyną, gdzie wymagano zaprzestania leczenia po 6 cyklach, co nie ma miejsca w rutynowej praktyce.

Podstawowym założeniem zastosowania PFS do oceny wartości leczenia systemowego przeciwnowotworowego jest twierdzenie, że jeżeli leczenie opóźnia progresję choroby, to chory żyje dłużej. Jednakże jak dotąd jedynie w kilku nowotworach wykazano, że wyniki PFS korelują 
Tabela I. Argumenty za i przeciw dla zastosowania PFS w ocenie skuteczności terapii przeciwnowotworowej

\begin{tabular}{ll}
\hline & Przeżycia od randomizacji do daty ostatniej oceny radiologicznej progresji nowotworu \\
\hline Za & - konieczność mniejszej liczebnie próby i mniejsze koszty badania \\
& - szybsze wyniki badania — krótszy okres obserwacji \\
& - na PFS nie ma wpływu cross-over lub kolejne linie leczenia \\
& - opiera się na obiektywnej i ilościowej ocenie \\
& - sposób pomiaru może być subiektywny lub niewłaściwy \\
& - generalizuje wyniki do całej populacji chorych \\
& - wyniki ulegają zmianie przy wprowadzeniu nowych terapii \\
& - nie mierzy późnej toksyczności leczenia \\
& - wymaga częstej oceny radiologicznej (np. co 6 tygodni) i w tych samych odstępach czasu w różnych ramionach badania \\
& - w niektórych przypadkach może być trudny do potwierdzenia \\
& - potwierdzono bezwzględnie jedynie w zaawansowanym raku jelita grubego i raku jajnika \\
\hline Cenzura $\quad$ Data ostatniej oceny radiologicznej nowotworu lub zgon chorego
\end{tabular}

z OS i w nich PFS może stanowić istotny punkt zastępczy dla OS - dotyczy to zaawansowanego raka jelita grubego, raka żołądka, raka nerki i raka jajnika [2-5]. Co więcej, w 3 badaniach klinicznych III fazy z losowym doborem chorych do zastosowania immunoterapii stwierdzono, nieco wbrew intuicji, że pomimo braku poprawy PFS wykazano wydłużenie OS (badanie z sipuleucelem T w zaawansowanym raku gruczołu krokowego i 2 badania z ipilimumabem u chorych na zaawansowane czerniaki) [6-8].

Z drugiej strony - dlaczego część metod leczenia, które wydłużają PFS, nie poprawia OS? Może to dotyczyć sytuacji niewłaściwej oceny PFS (np. różne długości cykli leczenia w obu ramionach, niewłaściwe metody oceny), zbyt małych lub zbyt dużych wyjściowo zmian nowotworowych (co nie znajduje pełnego odzwierciedlenia w stosowanych kryteriach odpowiedzi na leczenie) (tab. I), zastosowania aktywnego leczenia po progresji w jednym z ramion oraz toksyczności późnej leczenia, wpływającej negatywnie na początkowo korzystne wyniki terapii.

Generalnie z zastosowaniem PFS związanych jest wiele zagrożeń. Przede wszystkim dla wiarygodności PFS konieczna jest obiektywna ocena progresji choroby poprzez zaślepienie ramion badawczych, ocena odpowiedzi na leczenie w dokładnie tych samych punktach czasowych (gdyż inaczej prowadzi to do assessment time bias, jeżeli czas oceny ulega wahaniom lub jest niewłaściwy), niezależna ocena (np. radiologiczna), wyeliminowanie subiektywnej oceny progresji w badaniach obrazowych czy przy zastosowaniu markerów i właściwa ocena progresji (vide kryteria Choi versus RECIST w ocenie odpowiedzi na leczenie imatynibem w nowotworach podścieliskowych przewodu pokarmowego — GIST czy kryteria odpowiedzi immunologicznej przy leczeniu ipilimumabem chorych na czerniaki, uwzględniające zjawisko tzw. pseudoprogresji choroby). Innymi słowy, jeżeli opóźniona zostanie ocena PFS w badaniach obrazowych (np. z powodu awarii sprzętu), może to prowadzić do niewłaściwej oceny czasu progresji choroby.

Pomimo że FDA i EMA coraz częściej akceptują PFS jako główny punkt końcowy w wielu badaniach klinicznych z randomizacją (szczególnie ich wynikiem jest istotna duża bezwzględna wartość poprawy PFS), to w większości przypadków nie opiera się to na istniejących danych, że poprawa PFS przekłada się na poprawę OS lub jakości życia — nadal złotym standardem dla rejestracji nowych terapii jest istotne statystycznie wydłużenie OS i/lub jakości życia (QoL). W chwili obecnej można przyjąć, że OS jest bezwzględnie najlepszym punktem końcowym oceny leczenia, gdy mediana przeżycia po progresji choroby podczas leczenia jest krótka i nie przekracza 12 miesięcy [9].

\section{Prof. dr hab. n. med. Piotr Rutkowski}

Klinika Nowotworów Tkanek Miękkich, Kości i Czerniaków

Centrum Onkologii — Instytut

im. Marii Skłodowskiej-Curie w Warszawie

ul. Roentgena 5, 02-781 Warszawa

e-mail:piotr.rutkowski@coi.pl

Otrzymano i przyjęto do druku 28 lipca 2015 r.

Na podstawie wystąpienia podczas III Konferencji Naukowej czasopisma Nowotwory „Debaty onkologiczne”, 10-11 kwietnia 2015 roku.

\section{Piśmiennictwo}

1. Booth CM, Eisenhauer EA. Progression-free survival: meaningful or simply measurable? J Clin Oncol 2012; 30: 1030-1033.

2. Saad ED, Katz A, Hoff PM i wsp. Progression-free survival as surrogate and as true end point: insights from the breast and colorectal cancer literature. Ann Oncol 2010; 21: 7-12.

3. Shitara K, Ikeda J, Yokota T i wsp. Progression-free survival and time to progression as surrogate markers of overall survival in patients with advanced gastric cancer: analysis of 36 randomized trials. Invest New Drugs 2012; 30: 1224-1231.

4. Buyse M, Burzykowski T, Carroll K i wsp. Progression-free survival is a surrogate for survival in advanced colorectal cancer. J Clin Oncol 2007; 25: 5218-5224.

5. Sherrill B, Kaye JA, Sandin R i wsp. Review of meta-analyses evaluating surrogate endpoints for overall survival in oncology. Onco Targets Ther 2012; 5: 287-296.

6. Kantoff PW, Higano CS, Shore ND i wsp; IMPACT Study Investigators. Sipuleucel-T immunotherapy for castration-resistant prostate cancer. N Engl J Med 2010; 363: 411-422.

7. Hodi FS, O'Day SJ, McDermott DF i wsp. Improved survival with ipilimumab in patients with metastatic melanoma. N Engl J Med 2010; 363: 711-723.

8. Robert $C$, Thomas L, Bondarenko I i wsp. Ipilimumab plus dacarbazine for previously untreated metastatic melanoma. N Engl J Med 2011; 364: 2517-2526.

9. Broglio KR, Berry DA. Detecting an overall survival benefit that is derived from progression-free survival. J Natl Cancer Inst 2009; 101: 1642-1649. 